The Chittagong Univ. J. B. Sci., Vol. 5(1 \&2):55-62, 2010.

\title{
EFFECT OF FOLIAR APPLICATION OF IAA AND GA 3 ON SEX EXPRESSION, YIELD ATTRIBUTES AND YIELD OF BITTER GOURD (MOMORDICA CHARANTIA L.)
}

PERVIN AKTER AND M. A. RAHMAN *

Department of Botany, University of Chittagong, Chittagong-4331, Bangladesh

\begin{abstract}
Three concentrations of each of IAA viz. $2.5\left(\mathrm{~T}_{1}\right), 5.0\left(\mathrm{~T}_{2}\right)$ and $10\left(\mathrm{~T}_{3}\right) \mathrm{ppm}$ and $\mathrm{GA}_{3}$ viz. $2.5\left(\mathrm{~T}_{4}\right), 5.0\left(\mathrm{~T}_{5}\right)$ and $10\left(\mathrm{~T}_{6}\right)$ ppm were applied as foliar spray on bitter gourd. Results showed a positive stimulatory effect in the increase of female flowers at $T_{3}$ where the male to female sex ratio was the lowest. The number of fruits, fresh weight of fruits and yield per plant were also found to be the highest at $\mathrm{T}_{3}$.
\end{abstract}

Key words: Bitter gourd, sex expression, yield, IAA, GA . $_{3}$

\section{INTRODUCTION}

Momordica charantia L. a member of the family Cucurbitaceae is a native of tropical regions of Asia with extensive distribution in China, Japan, South East Asia, Polynesia and also in Africa (Jeffery 1967). The immature fruits are a good source of vitamin $\mathrm{C}$ and provide some vitamin $\mathrm{A}$, phosphorus and iron. It is fast growing, trailing or climbing with their stem and tendrils. It is an economically important plant as it is used to combat for cancer, diabetes and many infectious diseases (Shetty et al. 2005). It is a powerful weapon against immunodeficiency virus (HIV) (Sikder 2004). The average yield of bitter gourd is $13.84 \mathrm{mt}$ per hectare which seems to be low (BBS 2005). In cucurbits male flowers are found to bloom at the lower nodes and female flowers appear a week later and never bloom first before the male flowers (Sumpoudlek and Abella 1974). As a crop bitter gourd has a number of problems viz. low seed germination, small and Dshaped fruit, low yield, non-synchronous flowering and diseases (Sikder 2004).

Plant growth regulators like IAA and $\mathrm{GA}_{3}$ have remarkable effect on the sex expressions and yield and fruit characteristics in cucurbitaceous crops. But information on the application of foliar spray of these two phytohormones in

\footnotetext{
* Corresponding author : E-mail: azizurrahmancu@yahoo.com
} 
bitter gourd are scanty. The present investigation was undertaken to study effects of foliar spray of different concentration of IAA and $\mathrm{GA}_{3}$ on the number of female flowers, male to female sex ratio, yield and yield attributes of bitter gourd.

\section{MATERIALS AND METHODS}

A pot experiment was carried out in Kharif season during 2009 in the department of Botany, University of Chittagong. The seeds of bitter gourd var. Shahparan were collected from the Society Nursery, Chittagong, Bangladesh.

There were altogether seven treatments viz. $\mathrm{T}_{0}$ (Control), $\mathrm{T}_{1}-2.5 \mathrm{ppm}$ IAA, $\mathrm{T}_{2}-5.0 \mathrm{ppm}$ IAA, $\mathrm{T}_{3}-10$ ppm IAA, $\mathrm{T}_{4}-2.5 \mathrm{ppm} \mathrm{GA}_{3}, \mathrm{~T}_{5}-5.0 \mathrm{ppm} \mathrm{GA}_{3}$ and $\mathrm{T}_{6}-10$ ppm $\mathrm{GA}_{3}$. A trireplicated RCBD (Randomized Complete Block Design) was maintained in the present investigation. There were 3 pots per treatment and total number of pots was 21 . Each pot measures $30 \mathrm{~cm} \times 30 \mathrm{~cm}$ and filled up with a mixture of $10 \mathrm{~kg}$ loamy soil, $5 \mathrm{~kg}$ decomposed cowdung, $200 \mathrm{~g}$ T.S.P and $115 \mathrm{~g}$ M.P. following Paleda and Chang (2003) and left in sun for 7 days. Five seeds were sown in each pot on March 5, 2009. The average percentage of germination was above 80. After germination three uniform seedlings were kept per pot and the rests were thinned out. Irrigation, weeding and other cultural practices were done as and when required.

The above mentioned concentration of IAA and $\mathrm{GA}_{3}$ were sprayed on a sunny morning when seedlings were at four leaf stage. The control plants $\left(\mathrm{T}_{0}\right)$ were sprayed with only distilled water. The number of male and female flowers (opened and bud condition) were counted and continued at 15 days interval till final harvest. The male to female sex ratio was calculated. Node number at which first male and female flowers appeared were also recorded. The fruits of bitter gourd were harvested at marketable stage. The numbers of fruits per plant, fresh weight, length, flesh thickness, cavity, diameter, circumference per fruit were measured just immediately after harvest. The yield per plant was calculated by multiplying the number of fruits per plant and fresh weight per fruit. Analysis of variance (ANOVA) was done to show the significant differences among the treatments. 


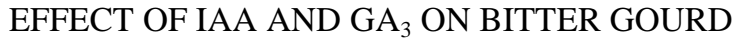

\section{RESULTS AND DISCUSSION}

Different concentrations of IAA and $\mathrm{GA}_{3}$ were found effective in the increase of male and female flowers, yield attributes and yield of bitter gourd. The results are presented in Table 1,2 and 3.

As compared to control the number of female flowers increased significantly following growth regulator treatments except at $T_{1}$ and $T_{6}$. At $T_{1}$ and $\mathrm{T}_{6}$ non-significant increases were found. The highest number of female flowers was found at $\mathrm{T}_{3}$ (Table 1). The increase in number of female flowers due to application of asafoetida and $\mathrm{GA}_{3}$ were reported by Choudhury and Elkholy (1970) in water melon and Kalia and Dhillon (1966) in Lagenaria siceraria, respectively. This corroborates with the findings of Ghosh and Basu (1983) who obtained increased number of female flowers due to application of IAA in bitter gourd. Rahman and Shormeen (1999) reported increase of number of female flowers in sweet gourd due to application of IAA. This observation corroborates with the findings of Ashrafuzzaman et al. (2009) who also obtained increased number of female flowers in bitter gourd due to the application of GABA. According to Shannon and Guarding (1969) the effect of auxin on sex expression is through an ethylene formation process. Iwahori et al. (1970) reported enhanced female sex expression in cucurbits following several growth regulators.

The number of male flowers decreased significantly at $T_{2}, T_{3} T_{4}$ and $T_{6}$. The lowest number of male flowers was found at $\mathrm{T}_{3}$ (Table 1). The suppression of number of male flowers was also reported by Gaur and Joshi (1965) with IAA application on Lagenaria siceraria and Surendranath and Rao (1981) in cucumber following application of growth regulators. The total number of flowers decreased following all the treatments except at $T_{5}$, but significantly decreased at $T_{3}$ and $T_{6}$. (Table 1).

The male flower appeared at significantly lower number of nodes in all the treatments except at $T_{6}$ but the difference at $T_{6}$ was nonsignificant. Male flowers appeared at the lowest number of nodes at $T_{3}$. The female flower also appeared at significantly lower number of nodes in all the treatments from control. The appearance of first female flowers at lower node due to IAA treatment of the present investigation was consistent with the findings of Gaur and Joshi (1965). Different concentrations of IAA and $\mathrm{GA}_{3}$ initiated lower male to female sex ratio from control and the lowest male to female sex ratio was found in $\mathrm{T}_{3}$ (Table 1). The highest male to female sex ratio was in $\mathrm{T}_{0}$. This agrees with the findings of Ashrafuzzaman et al. (2009). The decrease of male to female sex ratio due to IAA 
application is similar to the findings of Rahman et al. (1992). According to Surendranath and Rao (1981) the ratio of male and female flowers is determined by a balance of auxin and gibberellin; the balance in favor of auxin resulting in the formation of female and the latter of male flowers.

TABLE 1: EFFECT OF FOLIAR SPRAY OF IAA AND GA 3 AT FOUR LEAF STAGE ON NUMBER OF FLOWERS, NODE AT WHICH FIRST FLOWER APPEARED AND MALE TO FEMALE SEX RATIO OF MOMORDICA CHARANTIA VAR. SHAHPARAN.

\begin{tabular}{|c|c|c|c|c|c|c|}
\hline \multirow[t]{2}{*}{ Treatments } & \multicolumn{3}{|c|}{ Number of flowers/plant } & \multicolumn{2}{|c|}{$\begin{array}{l}\text { Node at which first } \\
\text { flower appeared }\end{array}$} & \multirow{2}{*}{$\begin{array}{c}\text { Sex ratio } \\
(\mathrm{M} / \mathrm{F})\end{array}$} \\
\hline & $\begin{array}{l}\text { Male } \\
(\mathrm{M})\end{array}$ & $\begin{array}{l}\text { Female } \\
\text { (F) }\end{array}$ & $\begin{array}{l}\text { Total } \\
\text { flowers } \\
(\mathrm{M}+\mathrm{F})\end{array}$ & M & $\mathrm{F}$ & \\
\hline $\begin{array}{c}\mathrm{T}_{0} \\
\text { (control) }\end{array}$ & $43.50 \mathrm{c}$ & $12.33 \mathrm{a}$ & $55.83 \mathrm{~d}$ & $12.66 \mathrm{~d}$ & $28.50 \mathrm{f}$ & $3.52 \mathrm{e}$ \\
\hline $\begin{array}{c}\mathrm{T}_{1} \\
(2.5 \mathrm{ppm} \text { IAA) }\end{array}$ & $42.25 b c$ & 13.00ab & $55.25 \mathrm{~b}$ & $8.0 \mathrm{a}$ & $18.00 \mathrm{~b}$ & $3.25 \mathrm{~d}$ \\
\hline $\begin{array}{c}\mathrm{T}_{2} \\
(5 \mathrm{ppm} \text { IAA) }\end{array}$ & $41.50 \mathrm{~b}$ & $14.00 \mathrm{~b}$ & $55.00 \mathrm{~d}$ & $9.33 b$ & $19.50 \mathrm{c}$ & $2.93 \mathrm{c}$ \\
\hline $\begin{array}{c}\mathrm{T}_{3} \\
(10 \mathrm{ppm} \text { IAA) }\end{array}$ & $36.00 \mathrm{a}$ & $16.50 \mathrm{c}$ & $52.50 \mathrm{c}$ & $7.66 \mathrm{a}$ & $16.00 \mathrm{a}$ & $2.18 \mathrm{a}$ \\
\hline $\begin{array}{c}\mathrm{T}_{4} \\
\left(2.5 \mathrm{ppmGA}_{3}\right.\end{array}$ & $41.50 \mathrm{~b}$ & $14.00 \mathrm{~b}$ & $55.50 \mathrm{~d}$ & $9.00 \mathrm{~b}$ & $21.05 \mathrm{~d}$ & $2.96 \mathrm{c}$ \\
\hline $\begin{array}{c}\mathrm{T}_{5} \\
\left(5 \mathrm{ppm} \mathrm{GA} \mathrm{GA}_{3}\right)\end{array}$ & $42.00 \mathrm{bc}$ & $15.00 \mathrm{~b}$ & $57.00 \mathrm{~d}$ & $11.33 \mathrm{~d}$ & $25.00 \mathrm{e}$ & $2.80 \mathrm{~b}$ \\
\hline $\begin{array}{c}\mathrm{T}_{6} \\
\left(10 \mathrm{ppm} \mathrm{GA}_{3}\right)\end{array}$ & $36.50 \mathrm{a}$ & $12.66 \mathrm{a}$ & $49.16 \mathrm{a}$ & $12.00 \mathrm{~cd}$ & $19.60 \mathrm{c}$ & $2.88 \mathrm{~b}$ \\
\hline S.E. \pm & 0.97 & 0.73 & 1.14 & 0.47 & 0.40 & 0.05 \\
\hline LSD0.05 & 1.72 & 1.30 & 2.03 & 0.83 & 0.71 & 0.08 \\
\hline
\end{tabular}

Means followed by a common letter(s) are not significantly different at the 5\% level. 


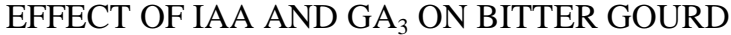

It was revealed from table 2 that the length of fruit significantly increased in all the treatments except at $T_{4}$. The highest length of fruit was obtained at $T_{3}$. The flesh thickness increased in all the treatments except at $\mathrm{T}_{6}$ and the highest was at $\mathrm{T}_{3}$. The cavity per fruit increased significantly in all the treatments except at $\mathrm{T}_{5}$. The circumference and diameter per fruit significantly increased in all the treatments and the highest value was found at $T_{3}$.

TABLE-2: EFFECT OF DIFFERENT CONCENTRATION OF FOLIAR SPRAY OF IAA AND $\mathrm{GA}_{3}$ AT FOUR LEAF STAGE ON THE FRUIT CHARACTERS OF MOMORDICA CHARANTIA VAR. SHAHPARAN.

\begin{tabular}{cccccc}
\hline Treatments & $\begin{array}{c}\text { Length } \\
(\mathrm{cm})\end{array}$ & $\begin{array}{c}\text { Flesh } \\
\text { thickness/ } \\
\text { fruit }(\mathrm{cm})\end{array}$ & $\begin{array}{c}\text { Cavity/fruit } \\
(\mathrm{cm})\end{array}$ & $\begin{array}{c}\text { Circumference } \\
(\mathrm{cm})\end{array}$ & $\begin{array}{c}\text { Diameter } \\
(\mathrm{cm})\end{array}$ \\
\hline $\mathrm{T}_{0}$ & $14.21 \mathrm{a}$ & $0.99 \mathrm{a}$ & $2.20 \mathrm{a}$ & $11.17 \mathrm{a}$ & $2.82 \mathrm{a}$ \\
$\mathrm{T}_{1}$ & $19.20 \mathrm{~cd}$ & $1.01 \mathrm{abc}$ & $2.46 \mathrm{bc}$ & $11.43 \mathrm{c}$ & $3.00 \mathrm{~b}$ \\
$\mathrm{~T}_{2}$ & $18.09 \mathrm{bc}$ & $1.03 \mathrm{bc}$ & $2.38 \mathrm{~b}$ & $11.53 \mathrm{~d}$ & $3.02 \mathrm{~b}$ \\
$\mathrm{~T}_{3}$ & $19.88 \mathrm{~cd}$ & $1.09 \mathrm{~d}$ & $2.55 \mathrm{c}$ & $11.88 \mathrm{f}$ & $3.11 \mathrm{~d}$ \\
$\mathrm{~T}_{4}$ & $15.44 \mathrm{ab}$ & $1.03 \mathrm{bc}$ & $2.38 \mathrm{~b}$ & $11.66 \mathrm{e}$ & $3.06 \mathrm{bcd}$ \\
$\mathrm{T}_{5}$ & $18.33 \mathrm{bcd}$ & $1.04 \mathrm{c}$ & $2.19 \mathrm{a}$ & $11.68 \mathrm{e}$ & $3.10 \mathrm{~cd}$ \\
$\mathrm{~T}_{6}$ & $17.57 \mathrm{bc}$ & $0.98 \mathrm{a}$ & $2.45 \mathrm{~b}$ & $11.34 \mathrm{~b}$ & $3.01 \mathrm{~b}$ \\
$\mathrm{~S} . \mathrm{E} \pm$ & 0.98 & 0.02 & 0.03 & 0.03 & 0.10 \\
LSD0.05 & 1.74 & 0.03 & 0.09 & 0.05 & 0.17
\end{tabular}

Means followed by a common letter(s) are not significantly different at the $5 \%$ level.

Results presented in table 3 shows that the number of fruits per plant though increased in all the treatments from control but significantly increased at $T_{1}, T_{3}$ and $T_{5}$. The highest number of fruits per plant was at $T_{3}$. The fresh weight per fruit significantly increased in all the treatments except at $T_{1}$ and the highest was at $T_{3}$. The yield per plant significantly increased at $T_{2}, T_{3}, T_{5}$ and $T_{6}$. The highest yield per plant was at $\mathrm{T}_{3}$ where number of fruits and fresh weight of fruits were also highest. The increase in yield due to IAA application of the present investigation agrees with the findings of Choudhury and Babel (1965) and Rahman et. al.(1992) on bottle gourd. 
TABLE 3: EFFECT OF DIFFERENT LEVELS OF FOLIAR SPRAY OF IAA AND GA 3 AT FOUR LEAF STAGE ON NUMBER OF FRUIT, FRESH WEIGHT, NO. OF SEEDS AND YIELD OF MOMORDICA CHARANTIA VAR. SHAHPARAN.

\begin{tabular}{cccc}
\hline $\begin{array}{c}\text { Treatments } \\
(\mathrm{T})\end{array}$ & No. of fruits /plant & Fresh weight/fruit (gm) & $\begin{array}{c}\text { Yield } \\
\mathrm{kg} / \mathrm{plant}\end{array}$ \\
\hline $\mathrm{T}_{0}$ & $10.00 \mathrm{a}$ & & \\
$\mathrm{T}_{1}$ & $11.00 \mathrm{~b}$ & $74.51 \mathrm{a}$ & $0.74 \mathrm{~b}$ \\
$\mathrm{~T}_{2}$ & $10.66 \mathrm{ab}$ & $74.52 \mathrm{a}$ & $0.51 \mathrm{a}$ \\
$\mathrm{T}_{3}$ & $12.33 \mathrm{c}$ & $79.39 \mathrm{c}$ & $0.84 \mathrm{c}$ \\
$\mathrm{T}_{4}$ & $10.00 \mathrm{a}$ & $79.83 \mathrm{c}$ & $0.98 \mathrm{e}$ \\
$\mathrm{T}_{5}$ & $11.66 \mathrm{bc}$ & $77.94 \mathrm{~b}$ & $0.77 \mathrm{~b}$ \\
$\mathrm{~T}_{6}$ & $10.66 \mathrm{ab}$ & $78.60 \mathrm{bc}$ & $0.91 \mathrm{~d}$ \\
S.E \pm & 0.44 & $77.67 \mathrm{~b}$ & $0.82 \mathrm{c}$ \\
LSD0.05 & 0.78 & 0.74 & 0.04 \\
\hline
\end{tabular}

Means followed by a common letters(s) are not significantly different at the $5 \%$ level.

Auxins and a number of plant growth regulators are known to cause physiological modifications in plants mainly on flowering behavior, sex ratio, increased fruit set, enlargement and development of fruits, and source-sink relation. Growth regulators bring certain changes in metabolism during fruit and seed development due to which there would be greater accumulation of food reserves resulting in higher yield. These beneficial effects of chemicals were also reported by Das and Das (1995) in pumpkin, Sitaram et al. (1988) and Rafeekher et al. (2002) in cucumber, Gedam et al. (1998) in bitter gourd and Balaraj (1999) in chilli.

In the present investigation $T_{3}$ concentration was found the most effective for the increase of number of female flowers and decrease of male to female sex ratio where the female flowers appeared at the lowest number of nodes of main vine. The number of fruits per plant and fresh weight per fruit were also found the highest in $\mathrm{T}_{3}$ which resulted the maximum yield per plant.

So, with the use of suitable concentration of IAA and $\mathrm{GA}_{3}$, keeping all other cultural practices at optimum level, it is possible to manipulate sex 
EFFECT OF IAA AND GA 3 ON BITTER GOURD

expression of bitter gourd and thereby good economic benefit may be achieved by increasing the number of female flowers with ultimate increase in yield.

\section{REFERENCES}

ASHRAFUZZAMAN, M., RAZI ISMAIL, M., ABDULLAH IBNE FAZAL, K.M, UDDIN, M.K. AND PRODHAN, A.K.M.A. 2009. Effect of GABA application on the growth and yield of bitter gourd (Momordica charantia L ). Int. J. Agric .Biol. 12:129-132.

BALARAJ, R. 1999. Investigation of seed technological aspects in chilli (Capsicum annuum L.). Ph.D. thesis, Univ. Agric. Sci., Dharwad, India.

BBS (BANGLADESH BUREAU OF STATISTICS), 2005. Monthly Statistical Bulletin of Bangladesh..Bangladesh Bureau of Statistics. Ministry of Planning. Government of People's Republic of Bangladesh, Dhaka, Bangladesh. P. 55.

CHOUDHURY, B. AND BABEL, Y.S. 1969. Studies on sex expression, sex ratio and fruit set as affected by different plant growth regulators sprays in Lagenaria siceraria (Mol.). Standl. Hort. Sci. 1(1):61-70.

CHOWDHURY, B. AND ELKHOLY, E. 1970. Chemical sex modification in watermelon (Citrullus vulgaris Schrad.). I. Effect of sex expression, sex ratio and fruiting. Hort. Sci. 2(2): 69-75.

DAS, B. C. AND DAS, T.K. 1995. Efficacy of $\mathrm{GA}_{3}$, NAA and Ethrel on sex expression in pumpkin (Cucurbita moschata Poir.) cv. Guamala Local. Orissa. J. Hort. 23: 87-91.

GEDAM, V.M., PATIL, R.B., SURYAWANSHI, Y.B AND MATE, S. N. 1998. Effect of plant growth regulators and boron on flowering, fruiting and seed yield in bitter gourd. Seed Research. 26:97-100.

GAUR, S. K. S. AND JOSHI D.P. 1965. Effect of 3-indole acetic acid on the growth and development of Lagenaria siceraria. Standl. (vern. Lauky). The Allahabad Farm. 39: 92-98.

GHOSH , S. AND BASU, P.S. 1983. Hormonal regulation of sex expression in Momordica charantia. Plant Physiol. 57:310-305.

KALIA , H.R. AND DHILLON. H.S. 1966. Comparative efficiency of asafoetida as a sex regulant in Lagenaria siceraria (Molina) Standl. J. Res. Punjab. Agr. Univ. Ludhiana.3:13-22.

IWAHORI, S.J., LYONS, J.M. AND SMITH, O.E.1970. Sex expression in cucumber plants as affected by 2-chloroethyl phosphoric acid, ethylene and growth regulators. Plant Physiol. 46: 412-415. 
JEFFERY, C. 1967. Cucurbitaceae. In: E. Milne-Redhead and R. M. Polhill R. M. (eds.), Flora of Tropical Africa. Crown Agents, London. P. 47-53.

PALEDA, M. C. AND CHANG, M.C. 2003. International Cooperation's Guide. Suggested Cultural Practices for bitter gourd. Asian Vegetable Research and Development Centre (AVRDC). Pub. 03-547.

RAFEEKHER, M., NAIR, S.A., SORTE, P. N., HATWAL, G. P. AND CHANDHAN, P. M. 2002, Effect of growth regulators on growth and yield of summer cucumber. J. Soils and Crops 12:108-110.

RAHMAN M.A. AND SHORMEEN 1999. Effect of IAA, GA 3 TIBA, B and Mo on sex expresssion and yield of Cucurbita moschata. Bangladesh J. Bot.. 28(1):79-83.

RAHMAN, M.A., ALAMGIR A.N.M. AND KHAN M. A. A. 1992 Effect of foliar application of IAA, GA3.TIBA and B on growth, sex expression and yield of bottle gourd. Trop. Agric. Res. 4:55-65.

SHANNON, S AND DE LA GUARDING, M.D. 1969. Sex expression and production of ethylene induced by auxin in the cucumber (Cucumis sativus L.). Nature. 223: 186-187.

SHETTY, A.K., KUMAR, G.S., SAMBAIAH, K. AND SALIMATH, P.V. 2005. Effect of bitter gourd (Momordica charantia) on glycaemic status in streptozotocin induced diabetic rats. Plant Foods Hum Nutr. 60:109-112.

SIKDER, B. 2004 Improvement of bitter gourd (Momordica charantia) through breeding and biotechnology. Ph.D thesis. Department of Genetics and Breeding, University of Rajshahi, Bangladesh.

SITARUM, HABIB, A. F. AND RUDRARADHYA, M. 1988, Effect of plant growth regulators and date of sowing on sex expression with special reference to seed production in Cucumis sativus L. variety Pickling melon. Seeds and Farm 14: 20-24.

SUMPOUDLEK, W. AND ABELLA, P. A. 1974. Effect of ethrel on sex expression and yield of cucumber. The CLSU. Sci. J. 10(1): 22-27.

SURENDRANATH K. AND RAO T.S. 1981. Influence of growth regulators on sex expression and sex ratio in cucumber (Cucumis sativus L.). The Andhra Agric. J. 28(3 and 4):127-128.

Manuscript received on 29. 7. 2010; Accepted on 29.9.11

The Chittagong University Journal of Biological Sciences, Vol. 5 (1 \& 2). Page No:55-62 